\title{
Firm Performance and Business Cycles: Implications for Managerial Accountability
}

\author{
Fabio Yoshio Suguri Motoki ${ }^{1} \&$ Carlos Enrique Carrasco Gutierrez ${ }^{2}$ \\ ${ }^{1}$ Universidade Federal do Espirito Santo - UFES, Brazil. \\ ${ }^{2}$ Universidade Catolica de Brasilia - UCB, Brazil. \\ Correspondence: Fabio Yoshio Suguri Motoki, Universidade Federal do Espirito Santo - UFES, Brazil.
}

Received: December 10, 2014

Accepted: December 31, 2014 Available online: January 26, 2015

doi:10.11114/afa.v1i1.647

URL: http://dx.doi.org/10.11114/afa.v1i1.647

\begin{abstract}
This study explores the relationship between firm performance and business cycles. These cycles are deviations from the trend of an economy-wide variable, in our case, GDP. Using a sample of Brazilian listed firms and accounting measures of performance, we find a generally positive contemporaneous relationship between the cycle and firm performance. Results also indicate that different industries show distinct relationships. This research presents a novel approach by linking firm performance from several industries to business cycles, indicating that managerial effort may be less determinant of firm performance than what is generally accepted. Our findings have potential implications for the design of more efficient compensation packages and to the study of managerial self-attributed performance.
\end{abstract}

Keywords: firm performance, business cycles, accountability, compensation, self-attribution

\section{Introduction}

This is an exploratory study on the relationship between firm performance and business cycles. Business cycles are also known as economic cycles: they are the deviations from the trend of an economy-wide variable, such as total output (GDP) (Kydland \& Prescott, 1982; Long \& Plosser, 1983). Although macroeconomic studies document a co-movement between business cycles variables (aggregate-level macroeconomic variables), little is known about firm performance during the ups and downs of the cycles. Understanding how firm performance is tied to the cycles has potential implications for the development of fair and efficient compensation packages for executives. Understanding this relationship is also relevant to sophisticated investors, who can discern more precisely how much of the performance is due to managers and how much is due to market conditions.

Our sample comprises Brazilian firms that traded in São Paulo Stock Exchange (Bovespa) from 1995 to 2005, and we use ROA and ROE as measures of firm performance. Results indicate that, in general, firms' performance and the business cycle exhibit a contemporaneous positive relation (procyclicality). There is also some persistence, with a positive relationship between firms' performance and the lagged cycle. When we break down by industry, results vary. Management of companies \& enterprises and Construction industries show no consistent relation. Retail trade, Utilities, and Manufacturing show strong procyclicality and some persistence. Information and Transportation \& warehousing show some contemporaneous and lagged procyclicality, although generally marginal. There is also leading countercyclicality from Utilities, Manufacturing, Information, and Transportation \& warehousing industries, indicating that when there is a future inversion of the cycle, their firms do not anticipate the turn.

Our evidence corroborates the predictions of Long \& Plosser (1983), that industries tend to move together in a procyclical pattern. However, our results are new in the sense that they do not measure aggregate activity levels, but firms' performance. Results indicate that executives may just surf the wave during booms - and get overcompensated but cannot do much during depressions - ending up undercompensated. A better understanding of the limits of managerial ability to influence outcomes may help designing compensation packages that better link pay to managerial effort. We have indication that firm performance and the macroeconomic environment are tightly linked, and that management effort may play a lesser role than what is currently believed. Boards and compensation committees should be aware of this in order to design fair and effective compensation packages. Furthermore, a more meaningful link between performance and compensation, e.g., controlling the measurement of performance for the macroeconomic environment, could help preventing executives' engagement in earnings management. 
Our evidence also contributes to studies on impression management ${ }^{1}$. Tessarolo, Pagliarussi, \& da Luz (2010) study this phenomenon in Brazil. The research is based on two distinct years, a "good" year and a "bad" one, and reports the same blaming of negative performance on external factors. If there is limited leeway on the influence managers have on performance, as our results indicate, then managers' narratives should be properly discounted. Furthermore, this knowledge of a more limited field of action could also prove useful to sophisticated investors, which could better evaluate predictions of managers regarding future firm performance due to managerial effort.

\section{Background}

Business cycles are the fluctuations of economy-wide variables around a long-term trend (Kydland \& Prescott, 1982; Long \& Plosser, 1983). Perhaps the most known variable is the GDP (gross domestic product), with levels below trend characterizing economic depression periods, and levels above trend being booms. Kydland \& Prescott (1982) shaped the current research on the theme, called "real business cycles" (RBC). The "real" denomination stems from the fact that it considers fluctuations (recessions and booms) as the efficient response to exogenous changes in the real economy.

According to Rebelo (2005), Kydland \& Prescott (1982) brought three revolutionary possibilities: studying business cycles using general equilibrium models, conciliating Solow-Swan's growth model and business cycles, and going beyond comparing qualitative properties of the model with observed facts. Of particular interest is Long \& Plosser (1983), who models the behavior of an economy with several different industries. Their model show how shocks propagate through industries, and predict that most industries should have positively related activity levels with the business cycles. This propagation includes timing differences, with some industries leading the cycle, some lagging the cycle, and others contemporaneously following the cycle. Several studies document such predicted pattern on actual macroeconomic variables, although the models do not explain all the observed facts, such as the volatility of some variables (Christiano \& Fitzgerald, 1998; Duda \& Sampaio, 2009; Ellery Jr., Gomes, \& Sachsida, 2002; Hornstein, 2000; Kanczuk \& Faria Jr, 2000; Val \& Ferreira, 2001).

In general, research based on business cycles deal with analysis on an aggregate level. There is very little study on the link between cycles and performance. As far as we are concerned, studies on this matter have been limited to the banking industry in a few countries. Athanasoglou, Brissimis, \& Delis (2008) explicitly use business cycles as defined by Hodrick \& Prescott (1997) as an explanatory variable of the profitability of Greek banks. They find that their profitability is procyclical. Dietrich \& Wanzenried (2011) also use GDP as a macroeconomic control to study the profitability of Swiss banks. However, they do not use cycles, but simply year-on-year real GDP growth. Interestingly, they do not find a significant relation between GDP growth and profitability. In this research, we extend the analysis to several industries from an important emerging market, namely Brazil. To document such phenomenon may be relevant to executive compensation policies, market analysts, sophisticated investors, and impression management research, as we detail next.

\subsection{On the Implications of the Relationship between Firms' Performance and the Business Cycle}

The relationship between firms' performance and the cycle may not be as straightforward as it seems. For instance, managerial ability could affect firm performance in such a way as to decouple the firms' performance from the cycle. Managers could also alter the temporal relation, delaying decreases in performance due to depressions and leading performance increases due to booms, mitigating the cycle effects. If this were true, then current pay for performance packages would be reasonable, since their aim is to reward managerial effort that increases the likelihood of firm success. Such ability to drive performance despite of the cycle could also have implications for the impression management literature and for market analysts, who could adjust the discount on managerial claims or promises.

Pay-for-performance compensation packages are quite pervasive, and firms with potentially greater agency problems are more prone to adopt them (Morgan \& Poulsen, 2001). As Tirole (2005) highlights, a first-best would be to compensate executives according to their effort, despite of the outcome. However, this is not attainable, since for any practical purposes effort is not observable. Therefore, a second-best solution is to design incentive mechanisms to align agents to the interests of principals based on some observable proxy for effort, which happens to be the firm's outcome, like its net income (Tirole, 2005). The outcome itself is stochastic. But if one assumes that the level of managerial effort changes the probabilities, so that more effort increases the probability of a positive outcome, a feasible solution is rewarding outcomes instead of effort (Tirole, 2005).

This research explores whether the assumption that managerial effort is the key determinant of the firm's likelihood of success is sufficient. It may be that cycles play an important role on the determination of firm performance, in spite of

\footnotetext{
${ }^{1}$ Impression management is about managers trying to induce the market into believing that "good" performance is the result of managerial dexterity and effort, while "bad" performance is the result of external, uncontrollable factors (Aerts, 1994, 2005).
} 
managerial effort. If this is the case, current pay-for-performance schemes should control for the cycle. In this fashion, managers could be compensated for firm performance, conditional on the business cycle. Good performance during economic booms would translate into not-so-high compensation, while bad performance during economic depressions would not hit managers so hard. This decrease in managerial risk may have benefits, like lowering overall compensation without losing incentives or even deterring earnings management, with implications for compensation and corporate governance policies.

A better knowledge of the relationship between performance and the business cycles may also have implications for the impression management literature. This literature argues that managers try to attribute good performance to their ability or effort, while bad performance would be the result of unfavorable external factors (Aerts, 1994, 2005; Tessarolo et al., 2010). This knowledge could also benefit sophisticated investors such as market analysts. If cycles do have a role in the determination of firm performance, then managers' discourse should be properly discounted, be it about past performance or about managerial ability to deliver results in the future. To the best of our knowledge, our research is the first one exploring this question. Next, we turn to our results.

\section{Data, Variables and Methods}

The main goal is to verify whether there is a relationship between firm performance and the business cycle. We use accounting measures of firm performance as our dependent variables, namely ROA (return on assets) and ROE (return on equity). Their main advantage on our setting is that they are not susceptible to the deviations from fundamentals to which financial market prices are subject to (Hirshleifer, 2001; Kahneman, 2003). This is important because the market may over- or under-react to news about the firm, especially during atypical economic periods such as deep recessions or pronounced booms. Furthermore, both ROA and ROE have been a staple measure of firm performance (Krause, Priem, \& Love, 2014; Masulis, Wang, \& Xie, 2012; Ovtchinnikov \& Pantaleoni, 2012). These measures are defined as follows:

$$
\begin{aligned}
& R O E_{i, t}=\frac{N I_{i, t}}{\left(E Q_{i, t}+E Q_{i, t}\right) / 2} \\
& R O A_{i, t}=\frac{N I_{i, t}}{\left(T A_{i, t}+T A_{i, t}\right) / 2}
\end{aligned}
$$

in which:

- $\quad N I_{i, t}$ is net income from firm $i$ on quarter $t$;

- $E Q_{i, t}$ is equity from firm $i$ on quarter $t$;

- $T A_{i, t}$ is total assets from firm $i$ on quarter $t$.

We obtain net income by taking total revenues and subtracting costs, expenses and taxes. Equity is the sum of equity capital, capital reserves, and adjustments to fair value, earnings reserves, treasury stock, and accumulated losses. Total assets are the sum of all assets and rights.

Two analyses support this research. In both we use a fixed-effects (FE) panel model with quarterly data to estimate the effects. We choose the FE model over the random-effects model after a modified Hausman test proposed by Arellano (1993) as implemented by Schaffer \& Stillman (2006). We use the modified Hausman because it always yields a positive test statistic, and it supports the clustered by firm variance-covariance matrix from the model. The FE panel is a special case of individual-specific effect models, which manage to capture both observed and non-observed heterogeneity of individuals, in our case, firms. Particularly, the FE panel allows each firm to have a different intercept, while all firms possess the same slope parameters, thus capturing their heterogeneity.

The first panel uses all firms from all industries together, as model (3) shows:

$$
\begin{aligned}
\operatorname{Perf}_{i, t}^{k}=\alpha_{i} & +\sum_{j=a}^{b}\left(\beta_{t+j} \cdot \text { Cycle }_{t+j}\right)+\beta_{x} \text { ExchRate }_{t}+\beta_{s} \text { Spread }_{t}+\beta_{t} \text { Tax }_{t}+\beta_{f} \text { FirmSize }_{i, t} \\
& +\beta_{h} \text { Herfindahl }_{s, t}+\epsilon_{i, t}
\end{aligned}
$$

in which:

- $\quad \operatorname{Per} f_{i, t}^{k}, k \in\{R O A, R O E\}$;

- $\quad$ Cycle $e_{t+j}$ is the business cycle as measured by the Hodrick-Prescott filter applied on the deseasonalized quarterly GDP series and $a, b$ are the parameters for the inclusion of the lagged or leading cycle; 
- ExchRate $_{t}$ is the real USD/BRL exchange rate;

- Spread $_{t}$ is the spread of the sovereign Brazilian bonds;

- $\operatorname{Tax}_{t}$ is the per-capita taxing;

- FirmSize $_{i, t}$ is firm size as measured by the natural logarithm of sales revenues;

- Herfindahl $l_{s, t}$ is the Herfindahl index from industry $s$; industry is the first-level NAICS;

- $\epsilon_{i, t}$ is the error term.

The inclusion of the lagged or leading cycles is controlled by parameters $a$ and $b$. We vary them so that there are six specifications: $(a, b) \in\{(-2,0),(-1,0),(0,0),(0,1),(0,2),(-1,1)\}$. In this way, up to two quarters of lags or leads are included in order to capture non-contemporaneous relationships between firm performance and the cycle.

The other variables are controls that may also influence firm performance. The exchange rate impacts firms with foreign trade operations: exporters benefit from a depreciated local currency, while importers benefit from an appreciated local currency. The spread of sovereign debt measures the risk of operating in the Brazilian market, and it is a control for the cost of capital embedded in the performance measures. Per capita tax controls for after-tax available income: more income may drive up consumption, thus affecting firm performance. We also include one industry-level control, the Herfindahl index, which proxies for the level of competitiveness between firms. More competitive industries should lead to less profitable firms (Hansen \& Wernerfelt, 1989). Finally, the firm-level control is firm size, since there could be economies of scale or diseconomies of scale due to firm size.

The second model is similar to the first, but it separates firms by industry. We separate industries using industry dummies, which we multiply by the cycle variables. We prefer this approach instead of running each industry separately because it yields one unique sample instead of several sub-samples with different sample sizes, making comparisons between industries straightforward. In this fashion, the new variable equals the cycle variable, if the firm belongs to industry $s$, or zero otherwise. Therefore, if there are $S$ distinct industries, then there are $S$ new Cycle Dummy variables, as equation

(4) shows. Variables and parameters are the same as in equation (3).

$$
\begin{aligned}
\operatorname{Perf}_{i, t}^{k}= & \alpha_{i}+\sum_{j=a}^{b} \prod_{s=1}^{S}\left(\beta_{t+j+k} \cdot \text { Cycle }_{t+j} \cdot \text { Dummy }_{s}\right)+\beta_{x} \text { ExchRate }_{t}+\beta_{s} \text { Spread }_{t}+\beta_{t} \text { Tax }_{t} \\
& +\beta_{f} \text { FirmSize }_{i, t}+\beta_{h} \text { Herfindahl }_{s, t}+\epsilon_{i, t}
\end{aligned}
$$

We expect the first approach from equation (3) to give a big picture of how firms' performance in general behave during business cycle. We refine this model into equation (4), which allows an analysis by industry, thus offering insight of how firms' from a given industry perform in relation to the cycle. Now, we turn to the data that feed these models.

\subsection{Data}

Macroeconomic data come from Ipeadata and the Brazilian Central Bank. Firm-level data is from Economatica. The sample contains Brazilian firms listed in the São Paulo Stock Exchange (Bovespa), and spans from quarter 1995Q1 to 2005Q4. We only keep industries with at least 15 distinct firms: Management of companies \& enterprises, Retail trade, Construction, Utilities, Manufacturing, Information, and Transportation \& warehousing. In this fashion, the sample comprises 11,169 firm-quarters, with 406 distinct firms over 40 quarters, as seen on Table 1.

Macroeconomic data is appended to the firm-level data, matching them by quarter. Using firm-level data, we build our performance proxies, ROA and ROE. The performance variables are winsorized at the $1 \%$ level, i.e., extreme values in the lower and upper tails are set equal to percentiles $0.5 \%$ and $99.5 \%$, respectively. The advantage over trimming is that there are no observation losses. Therefore, statistics become more robust to extreme values without losing degrees of freedom.

We derive the business cycle using a Hodrick-Prescott with parameter $\lambda=1600$, as usual for quarterly data (Cunha, Sandes, \& Vivanco, 2005; Hodrick \& Prescott, 1997; Ravn \& Uhlig, 2001). We filter the quarterly deseasonalized GDP per capita (gross domestic product) at constant price series, and it yields a trend - the long-term trend, which is upward - and the cycle itself, which are the variations around the trend. Above trend is a positive cycle (boom)|; below trend is a negative cycle (depression).

The exchange rate is the average ask (buy) BRL/USD rate, corrected by the Brazilian CPI (consumer price index), since the cycle is at constant prices. Spread refers to the spread, measured in basis points, between Brazilian sovereign bonds and US Treasury securities. We use the Brazilian C-Bonds spread series, but measurements were suspended in October 2005. To overcome this limitation, we also use the spread of the 40-year Brazilian Global Bond (BGR(40)), which 
began to be measured in September 2000. The resulting variable is a fusion of the two: from January/2000 to August $/ 2000$, it is the C-Bond spread, from September/2000 to November/2005, it is the average between the C-Bond and the Global Bond spread, and for November/2005 and December/2005, it is the BRG(40) spread. In the 62 quarters in common, the average C-Bond spread to BGR spread ratio is 0.95 and their correlation is 0.99 , that is, they are very similar indicators. Since they are monthly series, we turn them into a quarterly series by taking the arithmetic mean of the period. We calculate the quarterly per capita tax using estimations from Mendonça, dos Santos, \& Medrano (2009), since the tax series is yearly. This series is also deflated using the Brazilian CPI. All these macroeconomic variables are deseasonalized using the X-12 ARIMA program from the US Census Bureau. Lastly, we use their natural logarithm instead of their levels.

The firm-level control is firm size, defined as the natural logarithm of sales. We preferred this approach since total assets is the denominator of ROA. The industry-level control is the Herfindahl index. It is the sum of the squares of market participation of each firm, as measured by sales, normalized to the $[0,1]$ interval ${ }^{2}$. Consequently, the more competitive the market (the lower each firm participation), the closer to zero the index is.

Table 1 shows descriptive statistics. As expected, ROA is lower than ROE, since ROA controls for financial leverage. Separation by industry seems important, since firm and industry-level figures seem to vary considerably from industry to industry.

Table 2 shows the correlations. Note how the correlation between ROA and ROE is relatively low, supporting their choice as different performance indicators. No correlation seems to be too high. The largest ones are correlations of spread and per capita tax with exchange rate; however, they remain below 0.7.

Table 1. Descriptive Statistics

\begin{tabular}{|c|c|c|c|c|c|c|c|c|}
\hline \multirow{2}{*}{$\begin{array}{c}\text { Variables - means and standard } \\
\text { errors }\end{array}$} & \multicolumn{8}{|c|}{ Industries } \\
\hline & Management & Retail & Construction & Utilities & Manufacturing & Information & Transportation & All \\
\hline \multirow[t]{2}{*}{ ROA } & 0.0206 & 0.0337 & 0.0213 & 0.0182 & 0.0454 & 0.0216 & 0.0473 & 0.0377 \\
\hline & $(0.0457)$ & $(0.0940)$ & $(0.0273)$ & $(0.0254)$ & $(0.1142)$ & $(0.0330)$ & $(0.0700)$ & $(0.0962)$ \\
\hline ROE & 0.0615 & 0.0911 & 0.1093 & 0.0929 & 0.1337 & 0.0768 & 0.2870 & 0.1242 \\
\hline \multirow[t]{2}{*}{ Business cycle } & -0.0027 & -0.0016 & -0.0017 & -0.0014 & -0.0019 & -0.0016 & -0.0019 & -0.0018 \\
\hline & $(0.0168)$ & $(0.0174)$ & $(0.0167)$ & $(0.0165)$ & $(0.0179)$ & $(0.0161)$ & $(0.0158)$ & $(0.0174)$ \\
\hline \multirow[t]{2}{*}{ Exchange rate } & 1.0259 & 0.9712 & 1.0009 & 0.9944 & 0.9335 & 1.0106 & 1.0223 & 0.9581 \\
\hline & $(0.2226)$ & $(0.2460)$ & $(0.2348)$ & $(0.2373)$ & $(0.2551)$ & $(0.2251)$ & $(0.2205)$ & $(0.2494)$ \\
\hline Spread & $(0.4061)$ & $(0.3914)$ & $(0.3883)$ & $(0.4033)$ & $(0.3817)$ & $(0.3994)$ & $(0.4188)$ & $(0.3889)$ \\
\hline \multirow[t]{2}{*}{ Per capita tax } & 2.2733 & 2.2397 & 2.2536 & 2.2606 & 2.2153 & 2.2634 & 2.2809 & 2.2318 \\
\hline & $(0.1218)$ & $(0.1328)$ & $(0.1276)$ & $(0.1301)$ & $(0.1379)$ & $(0.1238)$ & $(0.1244)$ & $(0.1361)$ \\
\hline \multirow[t]{2}{*}{ Sales revenue } & 7.7857 & 11.2447 & 9.5722 & 12.2769 & 10.7137 & 12.3185 & 11.2100 & 10.9904 \\
\hline & $(3.5771)$ & $(2.3160)$ & $(1.3973)$ & $(1.3787)$ & $(1.9257)$ & $(1.6048)$ & $(2.3389)$ & $(2.0893)$ \\
\hline \multirow[t]{2}{*}{ Herfindahl index } & 0.7276 & 0.1975 & 0.0796 & 0.0349 & 0.0193 & 0.0777 & 0.2248 & 0.0606 \\
\hline & $(0.1697)$ & $(0.0751)$ & $(0.0333)$ & $(0.0195)$ & $(0.0075)$ & $(0.0305)$ & $(0.0810)$ & $(0.1182)$ \\
\hline Number of distinct firms & 16 & 22 & 17 & 49 & 241 & 41 & 20 & 406 \\
\hline Number of firm-quarters & 238 & 585 & 476 & 1478 & 7052 & 942 & 398 & 11169 \\
\hline
\end{tabular}

Descriptive statistics by first-level NAICS. ROA is net income divided by average total assets. ROE is net income divided by average equity. Business cycle is the business cycle as measured by the Hodrick-Prescott filter applied on the deseasonalized quarterly GDP series. Exchange rate is the real USD/BRL exchange rate. Spread is the spread of the sovereign Brazilian bonds. Per capita tax is the per-capita taxing. Firm size is firm size as measured by the natural logarithm of sales revenues. Herfindahl index is the Herfindahl concentration index for a given industry.

Table 2. Correlations

\begin{tabular}{|c|c|c|c|c|c|c|c|c|}
\hline \multirow{2}{*}{$\begin{array}{c}\text { Correlations } \\
\mathrm{N}=11169\end{array}$} & \multirow[b]{2}{*}{ ROA } & \multirow[b]{2}{*}{ ROE } & \multirow[b]{2}{*}{ Bus. cycle } & \multicolumn{2}{|c|}{ Variables } & \multirow[b]{2}{*}{$\mathrm{P} / \mathrm{c} \operatorname{tax}$} & \multirow[b]{2}{*}{ Sales rev. } & \multirow[b]{2}{*}{ Herfindahl } \\
\hline & & & & Exch. rate & Spread & & & \\
\hline ROA & 1.0000 & & & & & & & \\
\hline ROE & $0.2035^{* * *}$ & 1.0000 & & & & & & \\
\hline Business cycle & $0.0206^{*}$ & $0.0355 * * *$ & 1.0000 & & & & & \\
\hline Exchange rate & $0.0795 * * *$ & $0.0868 * * *$ & $-0.0956 * * *$ & 1.0000 & & & & \\
\hline Spread & $0.0270 * *$ & $0.0630 * * *$ & $-0.1706 * * *$ & $0.4472 * * *$ & 1.0000 & & & \\
\hline Per capita tax & $0.0704 * * *$ & $0.0418 * * *$ & $0.0294 * *$ & $0.6772 * * *$ & $-0.2197 * * *$ & 1.0000 & & \\
\hline Sales revenue & $-0.2361 * * *$ & $-0.0886 * * *$ & $0.0281 * *$ & $0.0800^{* * *}$ & $-0.0852 * * *$ & $0.1626 * * *$ & 1.0000 & \\
\hline Herfindahl index & $-0.0260 * *$ & -0.0033 & -0.0004 & $0.0734 * * *$ & -0.0041 & $0.1021 * * *$ & $-0.1602 * * *$ & 1.0000 \\
\hline
\end{tabular}

ROA is net income divided by average total assets. ROE is net income divided by average equity. Business cycle is the business cycle as measured by the Hodrick-Prescott filter applied on the deseasonalized quarterly GDP series. Exchange rate is the real USD/BRL exchange rate. Spread is the spread of the sovereign Brazilian bonds. Per capita tax is the per-capita taxing. Firm size is firm size as measured by the natural logarithm of sales revenues. Herfindahl index is the Herfindahl concentration index for a given industry.

${ }^{2} \mathrm{H}=\sum_{i=1}^{N} s_{i}^{2}, s_{i}^{2}$ is firm's i market share, $\mathrm{N}$ is the number of firms of a given industry. To normalize it to [0,1], we make $H_{n}=(H-1 / N) /(1-1 / N)$ 


\section{Results}

The first analysis derives from model (3), which does not separate estimators by industry. Results are on Table 3. All regressions are fixed-effects panel models, following the Hausman test, always significant at 5\%. Except for the specifications with $t=2$, all regressions have 11,169 observations, with 406 distinct firms. Specifications with $t=2$ have less observations because we do not include quarter 1994Q3 due to the implementation of the Real Plan in July/1994. The third quarter of this year still was a period of stabilization of the newly introduced currency, being a highly atypical period. All regressions use a robust, clustered by firm variance-covariance matrix, allowing for intra-group correlation.

Notice the positive relationship between both performance measures and the contemporaneous cycle, represented by column $C(t)$. Also notice that in the majority of cases there is a positive relationship with the one quarter lagged cycle, $C(t-1)$. Overall, evidence points to firm performance being positively correlated with the contemporaneous cycle, and that there is some persistence, as the relationship with the lagged cycle shows. This evidence agrees with results from Athanasoglou et al. (2008) for Greek banks. However, when we turn to the one quarter leading cycle, $C(t+1)$, there is a negative relationship. It seems that there is some "inertia", in the sense that one quarter before the cycle inverts, firm performance has not suffered any impact yet. Suppose a positive cycle in $t=0$, which will become a negative cycle in $t=1$, and positive performance in $t=0$, hence the negative sign. Therefore, on average, firm performance does not lead the cycle, but exhibits positive persistence.

As for the controls, only per capita tax and firm size show any relation to ROA, while only exchange rate has any relation with ROE. The positive sign for per capita tax is surprising, since we expected a negative relation. The negative sign for firm size suggests that diseconomies of scale dominate. In the following section, we disaggregate these effects by industry.

Table 3. Results for All Firms - Equation (3)

\begin{tabular}{|c|c|c|c|c|c|c|c|c|c|c|c|c|}
\hline & \multicolumn{5}{|c|}{ All industries - Business cycle } & \multicolumn{5}{|c|}{ Controls } & \multicolumn{2}{|c|}{ Statistics } \\
\hline & $\mathrm{C}(\mathrm{t}-2)$ & $\mathrm{C}(\mathrm{t}-1)$ & $\mathbf{C}(\mathbf{t})$ & $C(t+1)$ & $\mathbf{C}(\mathbf{t}+2)$ & Exch. rate & Spread & $\mathrm{P} / \mathrm{c} \operatorname{tax}$ & Herfindahl & Sales rev. & Hausman & $\mathbf{R 2}$ \\
\hline \multirow{10}{*}{$\underset{D}{D}$} & \multirow{10}{*}{$\begin{array}{l}0.0538^{*} \\
(0.0961)\end{array}$} & & $0.1624 * * *$ & & & 0.0104 & 0.0039 & $0.0771^{* * *}$ & 0.0436 & $-0.0108 * *$ & 0.0106 & 0.0380 \\
\hline & & & $(0.0000)$ & & & $(0.1936)$ & $(0.1233)$ & $(0.0008)$ & $(0.2478)$ & $(0.0195)$ & & \\
\hline & & $0.1425^{* * *}$ & $0.1778^{* * *}$ & & & 0.0116 & 0.0041 & $0.0758 * * *$ & 0.0393 & $-0.0109 * *$ & 0.0229 & 0.0397 \\
\hline & & $(0.0000)$ & $(0.0000)$ & & & $(0.1505)$ & $(0.1074)$ & $(0.0009)$ & $(0.2994)$ & $(0.0185)$ & & \\
\hline & & $0.1593 * * *$ & $0.2050^{* * *}$ & & & 0.0113 & $0.0047 *$ & $0.0766^{* * *}$ & 0.0394 & $-0.0111^{* *}$ & 0.0426 & 0.0400 \\
\hline & & $(0.0000)$ & $(0.0000)$ & & & $(0.1701)$ & $(0.0722)$ & $(0.0010)$ & $(0.3122)$ & $(0.0188)$ & & \\
\hline & & & $0.1775^{* * * *}$ & $-0.3606 * * *$ & & $0.0180^{* *}$ & -0.0014 & $0.0613^{* * *}$ & 0.0302 & $-0.0114^{* *}$ & 0.0310 & 0.0468 \\
\hline & & & $(0.0000)$ & $(0.0000)$ & & $(0.0282)$ & $(0.6118)$ & $(0.0054)$ & $(0.4252)$ & $(0.0151)$ & & \\
\hline & & & $0.1863 * * *$ & $-0.3608 * * *$ & 0.0153 & $0.0177 * *$ & -0.0012 & $0.0620^{* * * *}$ & 0.0301 & $-0.0114 * *$ & 0.0486 & 0.0468 \\
\hline & & & $(0.0000)$ & $(0.0000)$ & $(0.6605)$ & $(0.0292)$ & $(0.6755)$ & $(0.0040)$ & $(0.4279)$ & $(0.0151)$ & & \\
\hline \multirow{14}{*}{ 疍 } & \multirow{14}{*}{$\begin{array}{c}0.3554 * * \\
(0.0444)\end{array}$} & -0.0263 & $0.1753 * * *$ & $-0.3750 * * *$ & & $0.0180^{* *}$ & -0.0017 & $0.0609^{* * *}$ & 0.0305 & $-0.0114^{* *}$ & 0.0469 & 0.0468 \\
\hline & & $(0.4174)$ & $(0.0000)$ & $(0.0000)$ & & $(0.0274)$ & $(0.5624)$ & $(0.0054)$ & $(0.4215)$ & $(0.0151)$ & & \\
\hline & & & $0.8344 * * *$ & & & $0.1158^{* * *}$ & 0.0140 & 0.0304 & 0.1844 & -0.0011 & 0.0014 & 0.0178 \\
\hline & & & $(0.0000)$ & & & $(0.0004)$ & $(0.3643)$ & (0.5913) & $(0.1210)$ & $(0.8745)$ & & \\
\hline & & $0.6123^{* * *}$ & $0.9007 * * *$ & & & $0.1208 * * *$ & 0.0148 & 0.0251 & 0.1658 & -0.0016 & 0.0044 & 0.0195 \\
\hline & & $(0.0000)$ & $(0.0000)$ & & & $(0.0002)$ & $(0.3401)$ & $(0.6586)$ & $(0.1605)$ & $(0.8222)$ & & \\
\hline & & $0.7569^{* * *}$ & $1.0568 * * *$ & & & $0.1119^{* * *}$ & 0.0233 & 0.0310 & 0.1647 & -0.0009 & 0.0070 & 0.0198 \\
\hline & & $(0.0000)$ & $(0.0000)$ & & & $(0.0008)$ & $(0.1495)$ & $(0.5990)$ & $(0.1757)$ & (0.8988) & & \\
\hline & & & $0.8666 * * *$ & $-0.7657 * * *$ & & $0.1318^{* * *}$ & 0.0027 & -0.0031 & 0.1559 & -0.0023 & 0.0050 & 0.0200 \\
\hline & & & $(0.0000)$ & $(0.0000)$ & & $(0.0001)$ & $(0.8652)$ & $(0.9561)$ & $(0.1911)$ & $(0.7393)$ & & \\
\hline & & & $1.0380 * * *$ & $-0.7709 * * *$ & $0.2988^{*}$ & $0.1266^{* * * *}$ & 0.0078 & 0.0106 & 0.1538 & -0.0023 & 0.0095 & 0.0203 \\
\hline & & & $(0.0000)$ & $(0.0000)$ & $(0.0944)$ & $(0.0001)$ & $(0.6255)$ & $(0.8468)$ & $(0.1963)$ & $(0.7457)$ & & \\
\hline & & $0.3550^{* *}$ & $0.8969 * * *$ & $-0.5713^{* * *}$ & & $0.1306^{* * *}$ & 0.0060 & 0.0023 & 0.1524 & -0.0023 & 0.0107 & 0.0204 \\
\hline & & $(0.0356)$ & $(0.0000)$ & $(0.0035)$ & & $(0.0001)$ & $(0.7127)$ & $(0.9676)$ & (0.1997) & $(0.7440)$ & & \\
\hline
\end{tabular}

Fixed-effects panel regressions, with standard errors clustered by firm (406 distinct firms) for equation (3). The Hausman test is a variation of the Hausman test suggested by Arellano (1993). Except for the specifications with $t=2$, all regressions have 11,169 firm-quarters. Specifications with $t=2$ have 10,956 firm-quarters because quarter 1994Q3 is not included, due to the implementation of the Real Plan in July/1994. ROA is net income divided by average total assets. ROA is net income divided by average total assets. ROE is net income divided by average equity. Business cycle is the business cycle as measured by the Hodrick-Prescott filter applied on the deseasonalized quarterly GDP series. Exchange rate is the real USD/BRL exchange rate. Spread is the spread of the sovereign Brazilian bonds. Per capita tax is the per-capita taxing. Firm size is firm size as measured by the natural logarithm of sales revenues. Herfindahl index is the Herfindahl 
concentration index for a given industry.

\subsection{Analysis by Industry}

As before, all regressions are fixed-effects panels with standard errors clustered by firm. The difference is that now we run model (4), which separates effects by industry. Since it is a very long table, the complete version is located in Appendix A (Table 7,

Table 8, Table 9, and Table 10). For the comfort of the reader,

Table 4 presents summary results with the sign and significance of the estimators.

Table 4. Summary of Results by Industry - Equation

(4)

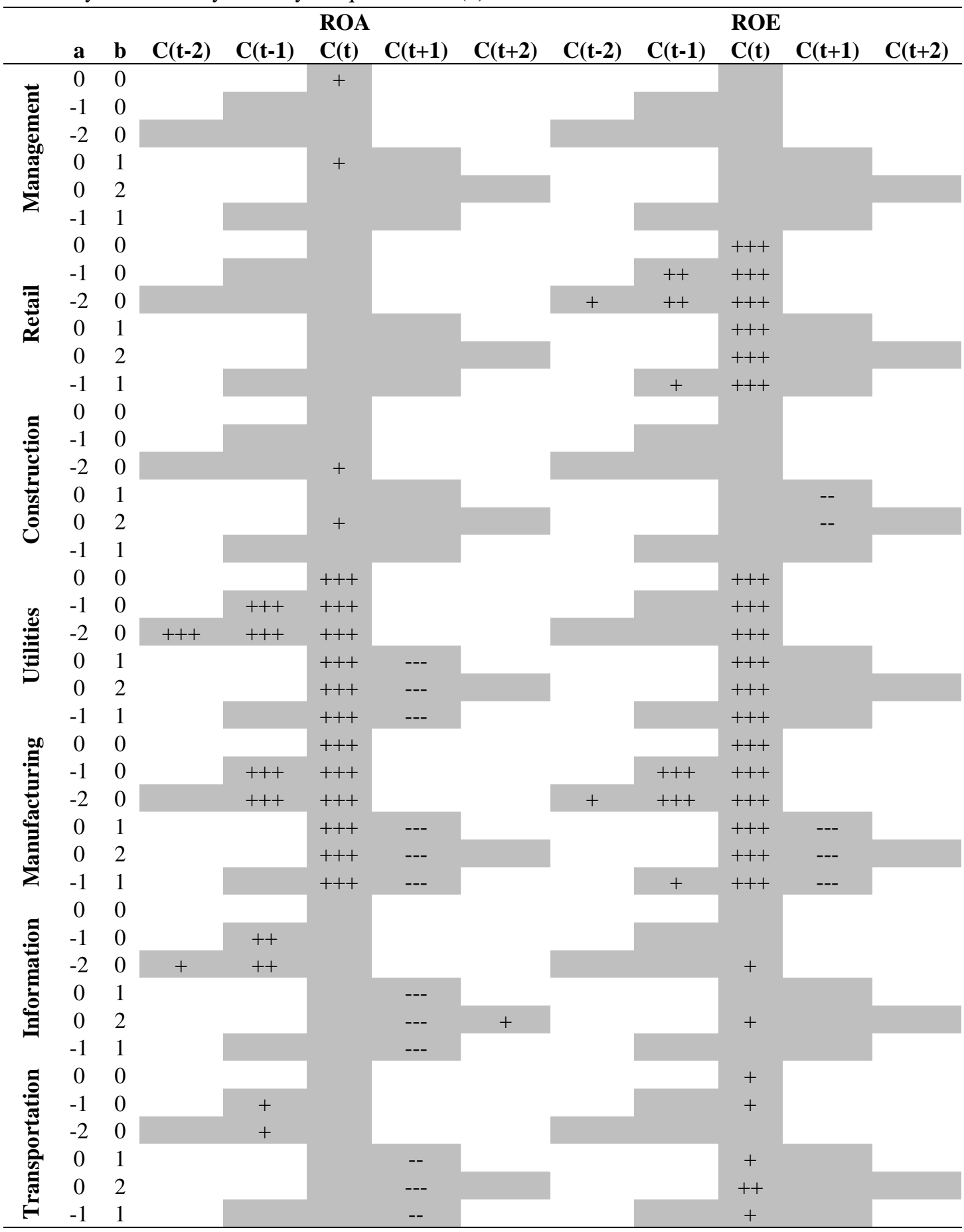

Summary of fixed-effects panel regressions by industry, with standard errors clustered by firm (406 distinct firms) for equation (4). Full results are in Table 7, Table 8, Table 9, and Table 10. Except for the specifications with $t=2$, all regressions have 11,169 firm-quarters. Specifications with $t=2$ have 10,956 firm-quarters because quarter 1994Q3 is not 
included, due to the implementation of the Real Plan in July/1994. The shaded areas represent the inclusion of lags and leads of cycle $C(\cdot)$, as dictated by parameters $a$ and $b .+++$ means a positive coefficient significant at $1 \%,++$ significant at $5 \%$, and + significant at $10 \%$. --- means a negative coefficient significant at $1 \%,-$ significant at $5 \%$, and - significant at $10 \%$.

\subsection{Management of Companies \& Enterprises and Construction}

These firms do not present a consistent relationship between firm performance and the business cycle. Management of companies \& enterprises consists of holdings and equity participation companies. A plausible explanation is that the observed behavior for the Management industry is due to a diversification effect. In the case of the Construction industry, it may be interesting to investigate the income elasticity of demand for housing. If it is relatively inelastic, one should expect little relation with the cycle. Research from Hornstein (2000) and Christiano \& Fitzgerald (1998) indicate contemporaneous procyclicality of economic activity level for the Construction industry in the US. However, none of these papers reports anything similar to the Management industry. The results indicate that compensation packages in these industries need not pay much attention to business cycles.

\subsubsection{Retail Trade}

Only ROE presents a significant relationship with the cycle. Unsurprisingly, it is a positive relationship. As this industry heavily depends on consumption, when the economy shows growth it is reasonable to think that these firms will perform well, and vice-versa. Notice that besides the contemporaneous relation, there is some persistence as well, as this industry shows significant positive relationships with up to two quarters lagged cycles. Christiano \& Fitzgerald (1998) report the same procyclicality in the US market, but for worked hours.

\subsubsection{Utilities}

This industry encompasses electric energy, gas and water firms. These are essential goods, and one could expect a relative inelastic demand regarding households (Taylor, 1975). However, for commercial and industrial customers, it may not be true. Our results point to a significant positive relationship between the performance of Utilities firms and the contemporaneous cycle. Moreover, in the case of ROA, there is also some persistence for up to two quarters. Our result is compatible with previous findings regarding economic activity levels in the US (Christiano \& Fitzgerald, 1998; Hornstein, 2000). This industry also presents a negative relationship between ROA and the one-quarter leading cycle, as in the aggregate analysis on model (3) reported in the beginning of this section.

\subsubsection{Manufacturing}

Manufacturing shows significant and consistent contemporaneous procyclicality, both for ROA and ROE. There is also some persistence: results indicate a positive relationship between performance and the cycle for up to two lagged quarters. These results agree with data from the US economy for activity levels (Christiano \& Fitzgerald, 1998; Hornstein, 2000). Just like Utilities, this industry also shows a negative relationship between performance and the leading cycle.

\subsubsection{Information}

This industry contains publishing, software, audiovisual, radio, cable TV, internet and telecommunications firms (US Census Bureau, 2007). For this industry, only ROA exhibits significant relationship with the cycle. There is procyclicality with up to two lagged quarters. There is also the countercyclicality with the one-quarter leading cycle, and marginal procyclicality with the two-quarter leading cycle. For the US, Hornstein (2000) reports marginal procyclicality (correlations around 0.5 ) of activity levels.

\subsubsection{Transportation \& Warehousing}

This industry shows ROA countercyclicality with the one-quarter leading cycle, and marginal ROA procyclicality with the two-quarter leading cycle, similar to the Information industry pattern. However, this industry also shows ROE contemporaneous procyclicality, although it is generally marginal. In contrast, this industry in the US exhibits strong activity level procyclicality (Christiano \& Fitzgerald, 1998; Hornstein, 2000).

\subsection{Robustness Test}

As a robustness test, we re-run model from equation absorb common year-level effects.

(4) including year dummies. In this fashion, these dummies

Table 5 holds the summary results for this specification. Note how, qualitatively, there is no major change in relation to the previous model without dummies. More often than not, results seen to be even stronger. Thus, our analysis remain unchanged. 
Table 6. Summary of Robustness Test by Industry - Equation $\quad$ (4) - Including Year Dummies

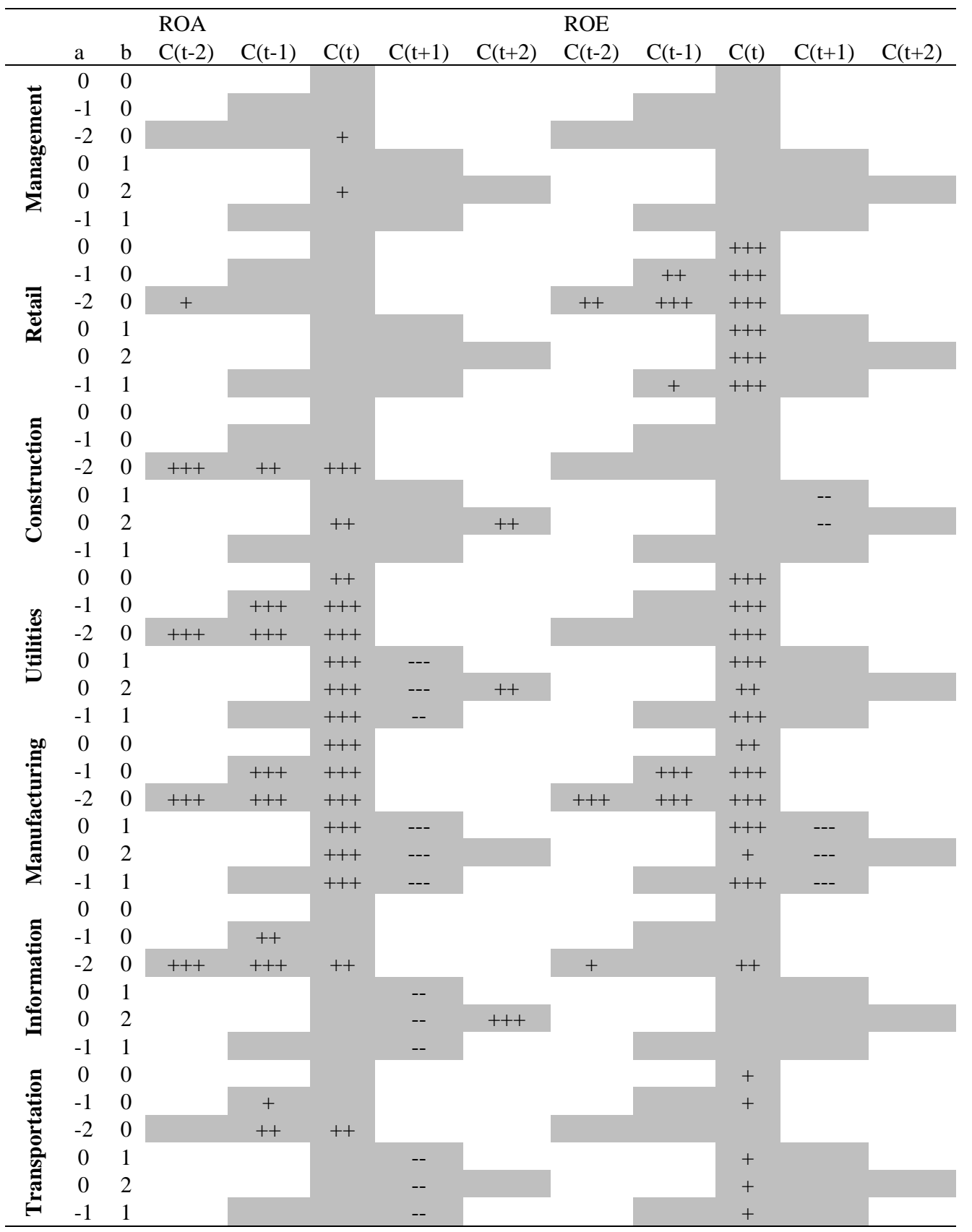

Summary of fixed-effects panel regressions by industry, with standard errors clustered by firm (406 distinct firms) for equation (4), with year dummies. Except for the specifications with $t=2$, all regressions have 11,169 firm-quarters. Specifications with $t=2$ have 10,956 firm-quarters because quarter 1994Q3 is not included, due to the implementation of the Real Plan in July/1994. The shaded areas represent the inclusion of lags and leads of cycle $\boldsymbol{C}(\cdot)$, as dictated by parameters $a$ and $b .+++$ means a positive coefficient significant at $1 \%,++$ significant at $5 \%$, and + significant at $10 \%$. --- means a negative coefficient significant at $1 \%$, -- significant at 5\%, and - significant at $10 \%$.

\section{Conclusion}

This research sheds light on how firm performance varies over the business cycles. As far as we are concerned, this is the first study exploring this relationship in several industries. Previous studies generally focus on the co-movement of macroeconomic variables related to levels of activity, not performance, and a few attempt to control for the business cycle to measure the determinants of banks' performance. We use data from firms listed in the São Paulo Stock Exchange (BM\&FBovespa) to build firm performance proxies ROA and ROE. Then, we add macroeconomic data, and run a panel data analysis with leading and lagging business cycles to uncover the relationship.

Results from Table 3, Table 4, and Table 5 indicate that firm performance is, in general, procyclical. Next, the 
relationship is investigated by industry, as defined by the first-level NAICS. Data indicate that some industries exhibit stronger procyclicality than others, while some do not show any significant relationships.

These findings may have practical implications. Our results suggest that compensation packages may be remunerating cycles instead of managers' efforts. In simple terms, managers may be overcompensated during booms, and undercompensated during recessions. Designing compensation packages that control for the cycles' effects may offer more efficient alignment mechanisms, which better link pay to managerial effort. Another possible implication is that managers' attribution of high or low firm performance should be interpreted with care, since firm performance seems to be so linked to the business cycle. The same advice is applicable to managers' promises on future performance: managerial influence on performance may be lower than what is currently accepted.

Although this is just an exploratory study, we believe it is an important step forward in exploring the relationship between firm performance and the business cycles. Understanding the relationship and its causes can have practical implications regarding executive compensation, corporate governance, and firm performance forecasting.

\section{References}

Aerts, W. (1994). On the use of accounting logic as an explanatory category in narrative accounting disclosures. Accounting, Organizations and Society, 19(4-5), 337-353. http://dx.doi.org/10.1016/0361-3682(94)90001-9

Aerts, W. (2005). Picking up the pieces: impression management in the retrospective attributional framing of accounting outcomes. Accounting, Organizations and Society, 30(6), 493-517. http://dx.doi.org/10.1016/j.aos.2004.07.001

Arellano, M. (1993). On the testing of correlated effects with panel data. Journal of Econometrics, 59(1-2), 87-97. http://dx.doi.org/10.1016/0304-4076(93)90040-C

Athanasoglou, P. P., Brissimis, S. N., \& Delis, M. D. (2008). Bank-specific, industry-specific and macroeconomic determinants of bank profitability. Journal of International Financial Markets, Institutions and Money, 18(2), 121-136. http://dx.doi.org/10.1016/j.intfin.2006.07.001

Christiano, L. J., \& Fitzgerald, T. J. (1998). The Business Cycle: It's Still a Puzzle. Federal Reserve Bank of Chicago Economic Perspectives, 22, 56-83.

Cunha, A. B., Sandes, J. R., \& Vivanco, L. G. C. (2005). Ciclos de Negócios na América do Sul e no Leste da Ásia: Uma Introdução. Brazilian Business Review, 2, 179-189.

Dietrich, A., \& Wanzenried, G. (2011). Determinants of bank profitability before and during the crisis: Evidence from Switzerland. Journal of International Financial Markets, Institutions and Money, 21(3), 307-327. http://dx.doi.org/10.1016/j.intfin.2010.11.002

Duda, F., \& Sampaio, A. V. (2009). Análise das flutuações econômicas no Brasil, de 1991 a 2008, a partir dos modelos RBC. Brazilian Review of Economics and Agribusiness, 7(2), 151-172.

Ellery Jr., R., Gomes, V., \& Sachsida, A. (2002). Business cycle fluctuations in Brazil. Revista Brasileira de Economia, 56, 269-308. http://dx.doi.org/10.1590/S0034-71402002000200004

Hansen, G. S., \& Wernerfelt, B. (1989). Determinants of firm performance: The relative importance of economic and organizational factors. Strategic Management Journal, 10(5), 399-411. http://dx.doi.org/10.1002/smj.4250100502

Hirshleifer, D. (2001). Investor Psychology and Asset Pricing. The Journal of Finance, 56(4), 1533-1597. http://dx.doi.org/10.1111/0022-1082.00379

Hodrick, R. J., \& Prescott, E. C. (1997). Postwar U.S. Business Cycles: An Empirical Investigation. Journal of Money, Credit, and Banking, 29(1), 1-16.

Hornstein, A. (2000). The Business Cycle and Industry Comovement. Federal Reserve Bank of Richmond Economic Quarterly, 86(1), 27-48.

Kahneman, D. (2003). Maps of Bounded Rationality: Psychology for Behavioral Economics. American Economic Review, 93(5), 1449-1475. http://dx.doi.org/10.1257/000282803322655392

Kanczuk, F., \& Faria Jr, F. C. P. (2000). Ciclos reais para a indústria brasileira. Estudos Econômicos, 30(3), 335-350.

Krause, R., Priem, R., \& Love, L. (2014). Who's in charge here? Co-CEOs, power gaps, and firm performance. Strategic Management Journal, n/a-n/a. http://dx.doi.org/10.1002/smj.2325

Kydland, F. E., \& Prescott, E. C. (1982). Time to Build and Aggregate Fluctuations. Econometrica, 50(6), 1345-70.

Long, J. B., \& Plosser, C. I. (1983). Real Business Cycles. The Journal of Political Economy, 91(1), 39-69.

Masulis, R. W., Wang, C., \& Xie, F. (2012). Globalizing the boardroom-The effects of foreign directors on corporate governance and firm performance. Journal of Accounting and Economics, 53(3), 527-554. 
http://dx.doi.org/10.1016/j.jacceco.2011.12.003

Mendonça, M. J., dos Santos, C. H., \& Medrano, L. A. (2009). Um modelo econométrico com parâmetros variáveis para a carga tributária bruta brasileira trimestral. IPEA.

Morgan, A. G., \& Poulsen, A. B. (2001). Linking pay to performance - compensation proposals in the S\&P 500. Journal of Financial Economics, 62(3), 489-523. http://dx.doi.org/10.1016/S0304-405X(01)00084-8

Ovtchinnikov, A. V., \& Pantaleoni, E. (2012). Individual political contributions and firm performance. Journal of Financial Economics, 105(2), 367-392. http://dx.doi.org/10.1016/j.jfineco.2012.03.007

Ravn, M. O., \& Uhlig, H. (2001, mai). On Adjusting the HP-Filter for the Frequency of Observations.

Rebelo, S. (2005, March). Real Business Cycle Models: Past, Present and Future.

Schaffer, M. E., \& Stillman, S. (2006). XTOVERID: Stata module to calculate tests of overidentifying restrictions after xtreg, xtivreg, xtivreg2, xthtaylor. Boston College Department of Economics. Retrieved from http://ideas.repec.org/c/boc/bocode/s456779.html

Taylor, L. D. (1975). The Demand for Electricity: A Survey. The Bell Journal of Economics, 6(1), 74-110.

Tessarolo, I. F., Pagliarussi, M. S., \& da Luz, A. T. M. (2010). The justification of organizational performance in annual report narratives. BAR - Brazilian Administration Review, 7, 198-212.

Tirole, J. (2005). The theory of corporate finance.

US Census Bureau. (2007). NAICS 2007 Definition File.

Val, P. R. da C., \& Ferreira, P. C. (2001). Modelos de ciclos reais de negócios aplicados à economia brasileira. Pesquisa E Planejamento Econômico, 31(2), 213-248.

\section{Appendix A - Full Results by Industry}

Table 7. Results by Industry (1/4)

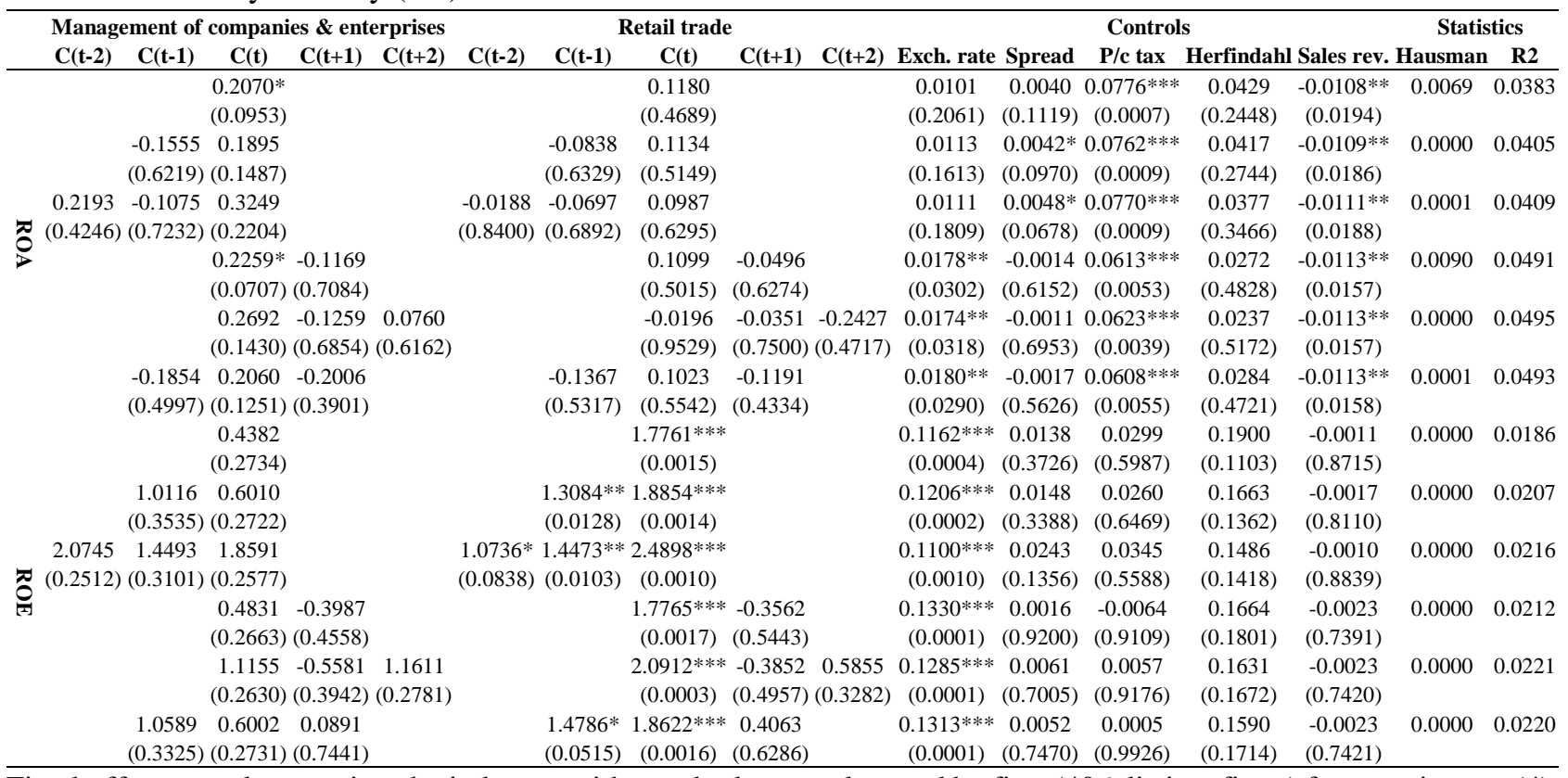

Fixed-effects panel regressions by industry, with standard errors clustered by firm (406 distinct firms) for equation (4). Results split across several tables due to paper size limitations. Except for the specifications with $t=2$, all regressions have 11,169 firm-quarters. Specifications with $t=2$ have 10,956 firm-quarters because quarter 1994Q3 is not included, due to the implementation of the Real Plan in July/1994. The shaded areas represent the inclusion of lags and leads of cycle $C(\cdot)$, as dictated by parameters $a$ and $b . * * *$ means a coefficient significant at $1 \%, * *$ significant at $5 \%$, and * significant at $10 \%$. ROA is net income divided by average total assets. ROA is net income divided by average total assets. ROE is net income divided by average equity. Business cycle is the business cycle as measured by the Hodrick-Prescott filter applied on the deseasonalized quarterly GDP series. Exchange rate is the real USD/BRL exchange rate. Spread is the spread of the sovereign Brazilian bonds. Per capita tax is the per-capita taxing. Firm size is firm size as measured by the natural logarithm of sales revenues. Herfindahl index is the Herfindahl concentration index for a given industry. 
Table 8 . Results by Industry (2/4)

\begin{tabular}{|c|c|c|c|c|c|c|c|c|c|c|c|c|c|c|c|c|c|}
\hline & \multicolumn{5}{|c|}{ Construction } & \multicolumn{5}{|c|}{ Utilities } & \multicolumn{5}{|c|}{ Controls } & \multicolumn{2}{|c|}{ Statistics } \\
\hline & $\mathrm{C}(\mathrm{t}-2)$ & $C(t-1)$ & $C(t)$ & $\mathbf{C}(\mathbf{t}+1)$ & $C(t+2)$ & $\mathrm{C}(\mathrm{t}-2)$ & $\mathrm{C}(\mathrm{t}-1)$ & $C(t)$ & $\mathbf{C}(\mathbf{t}+1)$ & $C(t+2)$ & Exch. rate & Spread & $P / c$ tax & Herfindahl & Sales rev. & Hausman & $\mathbf{R 2}$ \\
\hline \multirow{10}{*}{$\underset{D}{\pi}$} & \multirow{10}{*}{$\begin{array}{c}0.1507 \\
(0.1428)\end{array}$} & & 0.0544 & & & & & $0.1507 * * *$ & & & 0.0101 & 0.0040 & $0.0776^{* * *}$ & 0.0429 & $-0.0108^{* *}$ & 0.0069 & 0.0383 \\
\hline & & & $(0.3625)$ & & & & & $(0.0003)$ & & & $(0.2061)$ & $(0.1119)$ & $(0.0007)$ & $(0.2448)$ & $(0.0194)$ & & \\
\hline & & 0.0926 & 0.0637 & & & & $0.1295^{* * *}$ & $0.1604^{* * * *}$ & & & 0.0113 & $0.0042 *$ & $0.0762 * * *$ & 0.0417 & $-0.0109^{* *}$ & 0.0000 & 0.0405 \\
\hline & & $(0.1750)$ & $(0.3142)$ & & & & $(0.0037)$ & $(0.0002)$ & & & $(0.1613)$ & $(0.0970)$ & $(0.0009)$ & $(0.2744)$ & $(0.0186)$ & & \\
\hline & & 0.0918 & $0.1618 *$ & & & $0.1388 * * *$ & $0.1427 * * *$ & $0.2363^{* * *}$ & & & 0.0111 & $0.0048 *$ & $0.0770^{* * *}$ & 0.0377 & $-0.0111^{* *}$ & 0.0001 & 0.0409 \\
\hline & & $(0.2421)$ & $(0.0879)$ & & & $(0.0008)$ & $(0.0025)$ & $(0.0000)$ & & & $(0.1809)$ & $(0.0678)$ & $(0.0009)$ & $(0.3466)$ & $(0.0188)$ & & \\
\hline & & & 0.0599 & -0.1356 & & & & $0.1533^{* * *}$ & -0.1849 *** & & $0.0178^{* *}$ & -0.0014 & $0.0613 * * *$ & 0.0272 & $-0.0113 * *$ & 0.0090 & 0.0491 \\
\hline & & & $(0.3247)$ & $(0.2416)$ & & & & $(0.0002)$ & $(0.0000)$ & & $(0.0302)$ & $(0.6152)$ & $(0.0053)$ & $(0.4828)$ & $(0.0157)$ & & \\
\hline & & & $0.1389 *$ & -0.1469 & 0.1528 & & & $0.1868^{* * *}$ & $-0.1870^{* * * *}$ & 0.0675 & $0.0174 * *$ & -0.0011 & $0.0623 * * *$ & 0.0237 & $-0.0113^{* *}$ & 0.0000 & 0.0495 \\
\hline & & & $(0.0695)$ & $(0.1948)$ & $(0.1046)$ & & & $(0.0005)$ & $(0.0000)$ & $(0.1802)$ & $(0.0318)$ & $(0.6953)$ & $(0.0039)$ & $(0.5172)$ & $(0.0157)$ & & \\
\hline \multirow{14}{*}{ 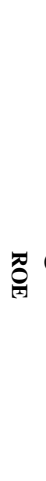 } & & 0.0425 & 0.0612 & -0.1159 & & & 0.0582 & 0.1549 *** & $-0.1557 * * *$ & & $0.0180^{* *}$ & -0.0017 & $0.0608 * * *$ & 0.0284 & $-0.0113^{* *}$ & 0.0001 & 0.0493 \\
\hline & & $(0.5927)$ & $(0.3286)$ & $(0.3769)$ & & & (0.1996) & $(0.0003)$ & $(0.0004)$ & & $(0.0290)$ & $(0.5626)$ & $(0.0055)$ & $(0.4721)$ & $(0.0158)$ & & \\
\hline & & & 0.3391 & & & & & $1.1990^{* * *}$ & & & $0.1162 * * *$ & 0.0138 & 0.0299 & 0.1900 & -0.0011 & 0.0000 & 0.0186 \\
\hline & & & (0.5010) & & & & & $(0.0001)$ & & & $(0.0004)$ & $(0.3726)$ & $(0.5987)$ & $(0.1103)$ & $(0.8715)$ & & \\
\hline & & 0.5197 & 0.3890 & & & & 0.3497 & 1.2319 *** & & & $0.1206^{* * *}$ & 0.0148 & 0.0260 & 0.1663 & -0.0017 & 0.0000 & 0.0207 \\
\hline & & (0.2977) & (0.4707) & & & & $(0.3954)$ & $(0.0001)$ & & & $(0.0002)$ & $(0.3388)$ & (0.6469) & $(0.1362)$ & $(0.8110)$ & & \\
\hline & -0.0675 & 0.7531 & 0.2186 & & & -0.0127 & 0.3860 & $1.2206^{* * * *}$ & & & $0.1100 * * *$ & 0.0243 & 0.0345 & 0.1486 & -0.0010 & 0.0000 & 0.0216 \\
\hline & $(0.9220)$ & $(0.2100)$ & (0.8128) & & & (0.9808) & (0.3724) & $(0.0057)$ & & & $(0.0010)$ & $(0.1356)$ & $(0.5588)$ & (0.1418) & $(0.8839)$ & & \\
\hline & & & 0.3760 & $-0.8259 * *$ & & & & $1.1999 * * *$ & -0.2718 & & $0.1330 * * *$ & 0.0016 & -0.0064 & 0.1664 & -0.0023 & 0.0000 & 0.0212 \\
\hline & & & (0.4533) & $(0.0185)$ & & & & $(0.0001)$ & $(0.3043)$ & & $(0.0001)$ & $(0.9200)$ & $(0.9109)$ & $(0.1801)$ & $(0.7391)$ & & \\
\hline & & & 0.8800 & $-0.8873^{* *}$ & 0.9685 & & & $1.1031^{* * * *}$ & -0.2557 & -0.2126 & $0.1285^{* * *}$ & 0.0061 & 0.0057 & 0.1631 & -0.0023 & 0.0000 & 0.0221 \\
\hline & & & $(0.2383)$ & $(0.0144)$ & (0.1689) & & & $(0.0026)$ & $(0.3337)$ & $(0.6670)$ & $(0.0001)$ & $(0.7005)$ & $(0.9176)$ & $(0.1672)$ & $(0.7420)$ & & \\
\hline & & 0.2282 & 0.3946 & -0.7068 & & & 0.2917 & 1.2214 *** & -0.1182 & & $0.1313^{* * *}$ & 0.0052 & 0.0005 & 0.1590 & -0.0023 & 0.0000 & 0.0220 \\
\hline & & (0.7366) & $(0.4585)$ & $(0.2167)$ & & & $(0.6010)$ & $(0.0001)$ & $(0.7869)$ & & $(0.0001)$ & $(0.7470)$ & (0.9926) & $(0.1714)$ & $(0.7421)$ & & \\
\hline
\end{tabular}

Fixed-effects panel regressions by industry, with standard errors clustered by firm (406 distinct firms) for equation (4). Results split across several tables due to paper size limitations. Except for the specifications with $t=2$, all regressions have 11,169 firm-quarters. Specifications with $t=2$ have 10,956 firm-quarters because quarter 1994Q3 is not included, due to the implementation of the Real Plan in July/1994. The shaded areas represent the inclusion of lags and leads of cycle $C(\cdot)$, as dictated by parameters $a$ and $b$. *** means a coefficient significant at $1 \%, * *$ significant at $5 \%$, and * significant at $10 \%$. ROA is net income divided by average total assets. ROA is net income divided by average total assets. ROE is net income divided by average equity. Business cycle is the business cycle as measured by the Hodrick-Prescott filter applied on the deseasonalized quarterly GDP series. Exchange rate is the real USD/BRL exchange rate. Spread is the spread of the sovereign Brazilian bonds. Per capita tax is the per-capita taxing. Firm size is firm size as measured by the natural logarithm of sales revenues. Herfindahl index is the Herfindahl concentration index for a given industry.

Table 9 . Results by Industry (3/4)

\begin{tabular}{|c|c|c|c|c|c|c|c|c|c|c|c|c|c|c|c|c|c|}
\hline & \multicolumn{5}{|c|}{ Manufacturing } & \multicolumn{5}{|c|}{ Information } & \multicolumn{5}{|c|}{ Controls } & \multicolumn{2}{|c|}{ Statistics } \\
\hline & $\mathrm{C}(\mathrm{t}-2)$ & $\mathbf{C}(\mathrm{t}-1)$ & $\mathbf{C}(\mathbf{t})$ & $\mathbf{C}(t+1)$ & $\mathbf{C}(\mathbf{t}+2)$ & $\mathrm{C}(\mathrm{t}-2)$ & $\mathbf{C}(\mathbf{t}-1)$ & $\mathbf{C}(\mathbf{t})$ & $\mathbf{C}(\mathbf{t}+1)$ & $\mathbf{C}(\mathbf{t}+2)$ & Exch. rate & Spread & $\mathbf{P} / \mathrm{c}$ tax & Herfindahl & I Sales rev. & Hausman & $\mathbf{R 2}$ \\
\hline \multirow{10}{*}{$\underset{D}{\ddot{0}}$} & & & $0.1924 * * *$ & & & & & -0.0168 & & & 0.0101 & 0.0040 & $0.0776^{* * *}$ & 0.0429 & $-0.0108 * *$ & 0.0069 & 0.0383 \\
\hline & & & $(0.0000)$ & & & & & $(0.8827)$ & & & $(0.2061)$ & $(0.1119)$ & $(0.0007)$ & $(0.2448)$ & $(0.0194)$ & & \\
\hline & & $0.1759 * * *$ & $* 0.2130 * * *$ & & & & $0.1101^{* *}$ & -0.0093 & & & 0.0113 & $0.0042^{*}$ & $0.0762 * * *$ & 0.0417 & $-0.0109^{* *}$ & 0.0000 & 0.0405 \\
\hline & & $(0.0000)$ & $(0.0000)$ & & & & $(0.0412)$ & $(0.9338)$ & & & $(0.1613)$ & $(0.0970)$ & $(0.0009)$ & $(0.2744)$ & $(0.0186)$ & & \\
\hline & 0.0285 & $0.1954^{* * *}$ & $* 0.2236 * * *$ & & & $0.1113^{*}$ & $0.1260^{* *}$ & 0.0422 & & & 0.0111 & $0.0048^{*}$ & $0.0770^{* * *}$ & 0.0377 & $-0.0111^{* *}$ & 0.0001 & 0.0409 \\
\hline & $(0.5323)$ & $(0.0000)$ & $(0.0000)$ & & & $(0.0578)$ & $(0.0233)$ & $(0.6852)$ & & & (0.1809) & $(0.0678)$ & $(0.0009)$ & $(0.3466)$ & $(0.0188)$ & & \\
\hline & & & $0.2149 * * *$ & $-0.4342 * * *$ & & & & -0.0155 & $-0.2081 * * *$ & & $0.0178 * *$ & -0.0014 & $0.0613^{* * *} *$ & 0.0272 & $-0.0113^{* *}$ & 0.0090 & 0.0491 \\
\hline & & & $(0.0000)$ & $(0.0000)$ & & & & $(0.8911)$ & $(0.0024)$ & & $(0.0302)$ & $(0.6152)$ & $(0.0053)$ & $(0.4828)$ & $(0.0157)$ & & \\
\hline & & & $0.2196^{* * *}$ & $-0.4340 * * *$ & 0.0072 & & & 0.0720 & $-0.2101^{* * *}$ & * $0.1918 *$ & $0.0174 * *$ & -0.0011 & $0.0623^{* * *}$ & 0.0237 & $-0.0113^{* *}$ & 0.0000 & 0.0495 \\
\hline & & & $(0.0000)$ & $(0.0000)$ & $(0.8829)$ & & & $(0.4973)$ & $(0.0026)$ & $(0.0669)$ & $(0.0318)$ & $(0.6953)$ & $(0.0039)$ & $(0.5172)$ & $(0.0157)$ & & \\
\hline \multirow{14}{*}{ 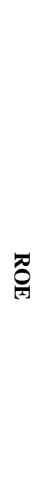 } & & -0.0298 & $0.2121 * * *$ & $-0.4508 * * *$ & & & 0.0177 & -0.0154 & $-0.2002 * * *$ & & $0.0180^{* *}$ & -0.0017 & $0.0608^{* * *}$ & 0.0284 & $-0.0113^{* *}$ & 0.0001 & 0.0493 \\
\hline & & $(0.5003)$ & $(0.0000)$ & $(0.0000)$ & & & $(0.7630)$ & (0.8904) & $(0.0081)$ & & $(0.0290)$ & $(0.5626)$ & $(0.0055)$ & $(0.4721)$ & $(0.0158)$ & & \\
\hline & & & $0.7322 * * *$ & & & & & 0.2736 & & & $0.1162 * * *$ & 0.0138 & 0.0299 & 0.1900 & -0.0011 & 0.0000 & 0.0186 \\
\hline & & & $(0.0000)$ & & & & & $(0.2711)$ & & & $(0.0004)$ & $(0.3726)$ & $(0.5987)$ & $(0.1103)$ & $(0.8715)$ & & \\
\hline & & $0.7123 * * *$ & $* 0.8171 * * *$ & & & & -0.1260 & 0.2790 & & & $0.1206^{* * *}$ & 0.0148 & 0.0260 & 0.1663 & -0.0017 & 0.0000 & 0.0207 \\
\hline & & $(0.0000)$ & $(0.0000)$ & & & & $(0.6886)$ & $(0.2601)$ & & & $(0.0002)$ & $(0.3388)$ & $(0.6469)$ & $(0.1362)$ & $(0.8110)$ & & \\
\hline & $0.3803^{*}$ & $0.9018^{* * *}$ & $* 0.9767 * * *$ & & & 0.3637 & -0.1050 & $0.4820 *$ & & & $0.1100^{* * *}$ & 0.0243 & 0.0345 & 0.1486 & -0.0010 & 0.0000 & 0.0216 \\
\hline & $(0.0783)$ & $(0.0000)$ & $(0.0000)$ & & & $(0.2687)$ & $(0.7522)$ & $(0.0903)$ & & & $(0.0010)$ & $(0.1356)$ & $(0.5588)$ & $(0.1418)$ & $(0.8839)$ & & \\
\hline & & & $0.7829 * * *$ & $-0.9869 * * *$ & & & & 0.2722 & -0.2275 & & $0.1330 * * *$ & 0.0016 & -0.0064 & 0.1664 & -0.0023 & 0.0000 & 0.0212 \\
\hline & & & $(0.0000)$ & $(0.0000)$ & & & & $(0.2767)$ & $(0.3022)$ & & $(0.0001)$ & $(0.9200)$ & (0.9109) & $(0.1801)$ & $(0.7391)$ & & \\
\hline & & & $0.8941 * * *$ & $-0.9863 * * *$ & 0.1791 & & & $0.5437 *$ & -0.2293 & 0.5846 & $0.1285^{* * *}$ & 0.0061 & 0.0057 & 0.1631 & -0.0023 & 0.0000 & 0.0221 \\
\hline & & & $(0.0001)$ & $(0.0000)$ & $(0.4373)$ & & & $(0.0858)$ & $(0.2931)$ & $(0.3469)$ & $(0.0001)$ & $(0.7005)$ & $(0.9176)$ & $(0.1672)$ & $(0.7420)$ & & \\
\hline & & $0.3530 *$ & $0.8162 * * *$ & $-0.7862 * * *$ & & & -0.2902 & 0.2696 & -0.3625 & & $0.1313^{* * *}$ & 0.0052 & 0.0005 & 0.1590 & -0.0023 & 0.0000 & 0.0220 \\
\hline & & $(0.0867)$ & $(0.0000)$ & $(0.0016)$ & & & $(0.4066)$ & $(0.2766)$ & $(0.1354)$ & & $(0.0001)$ & $(0.7470)$ & $(0.9926)$ & $(0.1714)$ & $(0.7421)$ & & \\
\hline
\end{tabular}


Fixed-effects panel regressions by industry, with standard errors clustered by firm (406 distinct firms) for equation (4). Results split across several tables due to paper size limitations. Except for the specifications with $t=2$, all regressions have 11,169 firm-quarters. Specifications with $t=2$ have 10,956 firm-quarters because quarter 1994Q3 is not included, due to the implementation of the Real Plan in July/1994. The shaded areas represent the inclusion of lags and leads of cycle $C(\cdot)$, as dictated by parameters $a$ and $b$. *** means a coefficient significant at $1 \%, * *$ significant at 5\%, and * significant at $10 \%$. ROA is net income divided by average total assets. ROA is net income divided by average total assets. ROE is net income divided by average equity. Business cycle is the business cycle as measured by the Hodrick-Prescott filter applied on the deseasonalized quarterly GDP series. Exchange rate is the real USD/BRL exchange rate. Spread is the spread of the sovereign Brazilian bonds. Per capita tax is the per-capita taxing. Firm size is firm size as measured by the natural logarithm of sales revenues. Herfindahl index is the Herfindahl concentration index for a given industry.

Table 10. Results by Industry (4/4)

\begin{tabular}{|c|c|c|c|c|c|c|c|c|c|c|c|c|}
\hline & & Transport & tation \& & warehousin & & & & Controls & & & Statis & stics \\
\hline & $\mathrm{C}(\mathrm{t}-2)$ & $\mathrm{C}(\mathrm{t}-1)$ & $\mathbf{C}(\mathbf{t})$ & $C(t+1)$ & $C(t+2)$ & $C(t-2) C(t-1) C(t) C(t+1) C(t+2)$ Exch. rate & Spread & $\mathbf{P} / \mathrm{c}$ tax & Herfindah & I Sales rev. & Hausman & $\mathbf{R} 2$ \\
\hline & & & 0.1600 & & & 0.0101 & 0.0040 & $0.0776^{\text {*** }}$ & 0.0429 & $-0.0108^{* *}$ & 0.0069 & 0.0383 \\
\hline & & & $(0.3163)$ & & & $(0.2061)$ & (0.1119) & $(0.0007)$ & $(0.2448)$ & $(0.0194)$ & & \\
\hline & & $0.2203^{*}$ & 0.1743 & & & 0.0113 & $0.0042 *$ & $0.0762^{* * * *}$ & 0.0417 & $-0.0109^{* *}$ & 0.0000 & 0.0405 \\
\hline & & $(0.0611)$ & $(0.2872)$ & & & $(0.1613)$ & $(0.0970)$ & $(0.0009)$ & $(0.2744)$ & $(0.0186)$ & & \\
\hline & 0.0122 & $0.2276^{*}$ & 0.1835 & & & 0.0111 & $0.0048 *$ & $0.0770^{* * *}$ & 0.0377 & $-0.0111^{* *}$ & 0.0001 & 0.0409 \\
\hline జ & $(0.9277)$ & $(0.0501)$ & $(0.2412)$ & & & $(0.1809)$ & $(0.0678)$ & $(0.0009)$ & $(0.3466)$ & $(0.0188)$ & & \\
\hline$>$ & & & 0.1724 & $-0.9024 * *$ & & $0.0178^{* *}$ & -0.0014 & $0.0613^{* * * *}$ & 0.0272 & $-0.0113^{* *}$ & 0.0090 & 0.0491 \\
\hline & & & $(0.3141)$ & $(0.0102)$ & & $(0.0302)$ & $(0.6152)$ & $(0.0053)$ & $(0.4828)$ & $(0.0157)$ & & \\
\hline & & & 0.1331 & $-0.9061 * * *$ & * -0.0906 & $0.0174 * *$ & -0.0011 & $0.0623^{* * * *}$ & 0.0237 & $-0.0113^{* *}$ & 0.0000 & 0.0495 \\
\hline & & & $(0.4938)$ & $(0.0099)$ & $(0.5361)$ & $(0.0318)$ & $(0.6953)$ & $(0.0039)$ & $(0.5172)$ & $(0.0157)$ & & \\
\hline & & -0.1999 & 0.1623 & $-0.9914 * *$ & & $0.0180 * *$ & -0.0017 & $0.0608 * * *$ & 0.0284 & $-0.0113 * *$ & 0.0001 & 0.0493 \\
\hline & & $(0.3540)$ & $(0.3414)$ & (0.0194) & & $(0.0290)$ & $(0.5626)$ & $(0.0055)$ & $(0.4721)$ & $(0.0158)$ & & \\
\hline & & & $2.2986^{*}$ & & & $0.1162 * * *$ & 0.0138 & 0.0299 & 0.1900 & -0.0011 & 0.0000 & 0.0186 \\
\hline & & & $(0.0530)$ & & & $(0.0004)$ & $(0.3726)$ & $(0.5987)$ & $(0.1103)$ & $(0.8715)$ & & \\
\hline & & 0.0927 & $2.3159^{*}$ & & & $0.1206^{* * * *}$ & 0.0148 & 0.0260 & 0.1663 & -0.0017 & 0.0000 & 0.0207 \\
\hline & & $(0.9300)$ & $(0.0527)$ & & & $(0.0002)$ & (0.3388) & $(0.6469)$ & $(0.1362)$ & $(0.8110)$ & & \\
\hline & -0.2933 & 0.1514 & 2.1611 & & & $0.1100^{* * * *}$ & 0.0243 & 0.0345 & 0.1486 & -0.0010 & 0.0000 & 0.0216 \\
\hline$\pi$ & $(0.8484)$ & $(0.8868)$ & $(0.1595)$ & & & $(0.0010)$ & $(0.1356)$ & $(0.5588)$ & $(0.1418)$ & $(0.8839)$ & & \\
\hline & & & $2.3033^{*}$ & -0.4785 & & $0.1330 * * *$ & 0.0016 & -0.0064 & 0.1664 & -0.0023 & 0.0000 & 0.0212 \\
\hline & & & $(0.0513)$ & (0.7524) & & $(0.0001)$ & (0.9200) & $(0.9109)$ & $(0.1801)$ & $(0.7391)$ & & \\
\hline & & & $3.2087 * *$ & -0.4919 & 2.0465 & $0.1285^{* * *}$ & 0.0061 & 0.0057 & 0.1631 & -0.0023 & 0.0000 & 0.0221 \\
\hline & & & $(0.0434)$ & $(0.7457)$ & $(0.1884)$ & $(0.0001)$ & $(0.7005)$ & $(0.9176)$ & $(0.1672)$ & $(0.7420)$ & & \\
\hline & & -0.1434 & $2.3041^{*}$ & -0.5493 & & $0.1313^{* * *}$ & 0.0052 & 0.0005 & 0.1590 & -0.0023 & 0.0000 & 0.0220 \\
\hline & & $(0.9131)$ & $(0.0550)$ & $(0.7594)$ & & $(0.0001)$ & $(0.7470)$ & $(0.9926)$ & $(0.1714)$ & $(0.7421)$ & & \\
\hline
\end{tabular}

Fixed-effects panel regressions by industry, with standard errors clustered by firm (406 distinct firms) for equation (4). Results split across several tables due to paper size limitations. Except for the specifications with $t=2$, all regressions have 11,169 firm-quarters. Specifications with $t=2$ have 10,956 firm-quarters because quarter 1994Q3 is not included, due to the implementation of the Real Plan in July/1994. The shaded areas represent the inclusion of lags and leads of cycle $C(\cdot)$, as dictated by parameters $a$ and $b$. *** means a coefficient significant at $1 \%$, ** significant at $5 \%$, and $*$ significant at $10 \%$. ROA is net income divided by average total assets. ROA is net income divided by average total assets. ROE is net income divided by average equity. Business cycle is the business cycle as measured by the Hodrick-Prescott filter applied on the deseasonalized quarterly GDP series. Exchange rate is the real USD/BRL exchange rate. Spread is the spread of the sovereign Brazilian bonds. Per capita tax is the per-capita taxing. Firm size is firm size as measured by the natural logarithm of sales revenues. Herfindahl index is the Herfindahl concentration index for a given industry.

\section{(cc) BY}

This work is licensed under a Creative Commons Attribution 3.0 License. 